\title{
Why People Strive to Get Rid of One's Own Gene from the World? A Psychological Analysis upon Terrorism
}

\author{
Kahsay Weldeslasie Hailemariam \\ Psychology Department, College of Social Sciences and Languages, Mekelle University, Mekelle, Ethiopia \\ Email: kasweld@gmail.com, kaspsyc@yahoo.com
}

Received 20 December 2015; accepted 4 January 2016; published 8 January 2016

Copyright (C) 2016 by author and OALib.

This work is licensed under the Creative Commons Attribution International License (CC BY). http://creativecommons.org/licenses/by/4.0/

(c) (i) Open Access

\begin{abstract}
Everybody remembers the April 19/2015 holocaust action committed by the ISIS terrorist group upon the Ethiopian Emigrants in the Libyan port. It was very immoral and devil action to behead and shoot people for the reason they do not know. In addition to that, it was the recent events to remember back about the massacre actions committed upon the France journalists and college students in Kenya who killed by the terrorist groups. For this inhuman and brutal action of the terrorist group, I initiated to make psychological analysis behind their behavior. I was also very eager to read different research findings about the true origin of human difference and why people strive to eliminate their own gene from the earth attributing human made differences. These and other questions are triggered me to make this psychological analysis. In the near future I will come up with detail investigation upon psychological view of terrorism.
\end{abstract}

\section{Keywords}

Terrorism, Get Rid of, Gene

Subject Areas: Psychology

\section{Introduction}

Terrorist activities have a long history. It was firstly used by the Jewish against Roman Empire as early as 66-72 A.D [1]. These small Jewish groups were named as Zealots. The second group which used terrorist activities was Assassin. It was a group of Shi'ite Muslims sect called Nizari Isma'ilis. They used to kill the enemies even at the expense of their own life. They created fear among the enemies through targeted killing of their opposition leaders [1]. These two groups considered it as a divine duty to use terrorist activities against enemy.

Terror and fear have been prominently displayed in the public domain since 11 September 2001. Modern 
technologies have made it possible to be up-to-date within seconds of anything happening around the world. The immediate transmissions of global news communicated through television and Internet connections straight into the private and personal environment have created an increased awareness of the global threats [2]. The concentrations on danger and alarming situations reinforce a fearful environment where the frightening situations come close up into people's everyday life scene even if the prospects are remote that such events would ever occur in the local community. Nowadays, terrorism has become part of people's everyday news information. To elucidate the meaning of terrorism, [3] developed a definition based on 109 separate classifications collated from scholars' responses to a questionnaire about "definitional elements" of terrorism.

Arab-Israel and Palestinian conflict gave birth to new strategies of terrorism like hijacking the airplanes. In 1960's Cuba supported the terrorist groups from all over the world [4]. This was the era when terrorism became a global phenomenon rather than local agenda as it was before. Terrorist activities were used as a tool for ending colonialism in the mid of the 20 century [5]. The Palestinian cause became the main focus of terrorist activities after the end of colonial period in 1960's. Arab defeat from Israel has given birth to a new kind of terrorism which was religion based terrorism. 1970s was the era of hijacking airplanes. In 1980s Americans supported Muslim Jihad of Afghanistan against Soviet Union. Mujahidin were given complete support and were provided modern weapons. This war was considered as a holy war by Muslims and Muslims from all over the world participated in it especially the students of Maddaris took part in war and were called as Taliban.

Osama Bin Laden also came from Saudi Arabia and was called a hero by the West. At that time Americans and West left the issue unresolved in Afghanistan. In 1990s former mujahidin and students of the same Maddrassa started Taliban movement with the preaching of Islam which was also followed in Saudi Arabia and other Persian Gulf [6]. After the first attack on world trade center in 1993, American turned against the Muslim Mujahidin [5]. Second attack of the terrorists on world center on 9/11 gave birth to a new conflict [1]. War on terrorism started and led by US against Al-Qaida changed the world scenario. American attacked the Afghanistan and terrorist activities started in the area, as history of theoretical attempt to understand the terrorism was derived from sub-discipline of collective violence in the discipline of political science [7].

"Terrorism is an anxiety-inspiring method of repeated violent action, employed by (semi-)secret individual, group, or state actors, for idiosyncratic, criminal, or political reasons, whereby in contrast to assassination the direct targets of violence are not the main targets. The immediate human victims of violence are generally chosen randomly (targets of opportunity) or selectively (representative or symbolic targets) from a target population, and serve as message generators. Threat and violence based communication processes between terrorist (organization), (imperiled) victims, and main target (audiences), turning it into a target of terror, a target of demands, or a target of attention, depending on whether intimidation, coercion, or propaganda is primarily sought" [3].

Why people endeavor to abolish their own gene from the world? People support or oppose others attributing human made differences like; religion, language, political view, ethnicity, race and other stereotypical attitudes. However, who creates these facades or nominations? The role of naming or giving facades to objects or people is simply to make categories or to have common understanding on symbols. "Name is simply a social convention that represents an object, idea or a person. The other reason for categorizing people might be for the purpose of dividing rule". Unless and otherwise, there is no any secret behind to categorize people based on race, religion, ethnicity, language, political ideology, etc. For example, Stone is the name given by the English speakers to a substance which is the collection of compressed soils and other ingredients however, this object has different names by different language speakers but its meaning is still the same that is stone.

Every human being is born with no attitude, interest, name, religious belief, political ideology, etc. These things are human made variables or artificial conventions for the sake of different reasons as mentioned in the above. Therefore, why people kill other individuals who are from the same human gene but with different human made codes?

Terrorists kill people for different reasons. Among the reasons firstly, terrorists kill people attributing human difference like, religion, language, skin color, political view, race, etc. However, these variables are human made or they do not show the true difference of human beings. Secondly, terrorists' aggressive behavior can be learned just like normal behaviors during the lifetime from violent films, violent parents and other significant individuals. As the behaviorists explained that, behavior (normal or abnormal) is learned from the environment.

We are not born with a genetic plan for life. Much of what we do learned from our experience [8]. Behaviorists have been accused of believing that the environment controls practically all aspects of behavior. The most 
extreme statement of environmental determinism came from John B. Watson, one of the founders of behaviorism, he said, "Give me a dozen healthy infants, well-formed, and my own specified world to bring them up in and I will guarantee to take any one at random and train him/her to become any type of specialist and with different personalities I might select doctor, lawyer, artist, merchant-chief, and yes, even beggar man thief regardless of his talents, penchants, tendencies, abilities, vocations, and race of his ancestors. I am going beyond my facts and I admit it, but so have the advocates of the contrary" [9].

Thirdly, any person may have a role model that can highly influential in his/her life positively or negatively. For instance, those who commit summary excision upon innocent individuals may be taken Hitler or Mussolini of Nazism and Fascism respectively as a role model. These cruel individuals may have a great value on the terrorists' life. In addition to the above, the terrorists may be influenced by other very influential actors in the violent films during their life time. People automatically imitate many other actions that they see, often with no apparent motivation [10]. If you see someone smile or frown, you briefly start to smile or frown. Your expression may be just a quick, involuntary twitch, and an observer may have to watch carefully to see it, but it often does occur. Even newborns imitate facial expressions [9].

Spectators at an athletic event sometimes move their arms or legs slightly in synchrony with what some athlete is doing. When expert pianists listen to a composition they have practiced, they start involuntarily tapping their fingers as if they were playing the music [11]. Similarly, people tend to copy the hand gestures they see [12]. You can demonstrate this tendency by telling someone, "Please wave your hands" while you clap your hands. Many people copy your actions instead of following your instructions.

Imitation relates to an exciting discovery in brain functioning known as mirror neurons, which are activated while you perform a movement and also while you watch someone else performing the same movement, such as reaching to grab an object. You identify with what someone else is doing, imagine what it would be like to make the same movement, and start activating cells that would make the movement [13] something similar happens in other brain systems. Watching someone showing an expression of disgust activates the same brain areas as if you were feeling disgusted yourself [14]. Mirror neurons are probably important for imitation and other social behaviors. However, we do not yet know how they develop. Are you born with mirror neurons, or do they develop as you learn how to identify with other people?

Albert Bandura studied the role of imitation for [9] learning aggressive behavior. They asked two groups of children to watch films in which an adult or a cartoon character violently attacked an inflated "Bobo" doll. Another group watched a different film. They then left the children in a room with a Bobo doll. Only the children who had watched films with attacks on the doll attacked the doll themselves, using many of the same movements they had just seen. The clear implication is that children copy the aggressive behavior they have seen in others. Generally, every human difference or personality is developed during the later ages in the stages of human development. But, there is little biological difference with in the human gene based on the above theoretical explanations.

According to the creation story in the genesis of the holy bible, God created Adam and Eve for the first time in this earth. Then after, he ordered them to multiply their own gene and to fill the earth. Therefore, all human beings are from the same gene or we are the son/daughter of Adam and Eve. Even scientists classify the biomass based on their respective species or gene. Example, animal species, human species, plant species, etc. therefore, all human beings are found in the same gene (i.e., human gene). But, the environment may make us to have different skin color, language, religion, personality, interest, political and life philosophy, etc. Even if we are coming from the same gene but, the way how we reared by our parents and other significant individuals, the way how models influenced our life, and the science we had learned in the classroom may be the critical factors to become some of us generous, cruel, considerate, aggressive, kind, devil, intelligent, etc. [8]. There is a proverb that mostly used by the Ethiopian society, "tell me your friends and I will tell you who you are". This is to mean that, the significant individuals have a great role molding one's personality and behavioral development.

\section{Psychological and Socio-Cultural Factors in Aggression}

What psychological factors may trigger aggressive behavior? Mistreatment during childhood period leads to aggressiveness during adult life [8]. Fail to achieve one's life goals also increases people to become more aggressive than people who are successful at their goals. People also often respond to stressful life events with a fight-or-flight reaction. After the frustration and stress of the September 9/11 terrorist attacks, Americans responded with a readiness to fight and flight [15]. 
Terrorism similarly may spring from a desire for revenge, sometimes after a friend or family member has been killed or injured by somebody else. After the death of Bin Laden, US want further for hunting other Al Qaida officials; this will increase anti American element in Pakistan. This aspect and drone attacks will increase terrorist activities in Pakistan [16]. Contrary to the popular idea that poverty breeds terrorists, suicide bombers and those who support them actually tend to be neither uneducated nor desperately poor [17].

Frustration and aggression arise less from deprivation than from the gap between reality and expectations, which may rise with education and attainments [15]. Like frustration, other aversive stimuli, physical pain, personal insults, foul odors, hot temperatures, cigarette smoke, and a host of others can also evoke hostility [17]. For example, violent crime and spousal abuse rates are higher during hotter years, seasons, months, and days. When people get overheated, they think, feel, and act more aggressively [8].

People or groups who want separate and independent land from external powers launch different form of movements. Difference in distribution of wealth, inequality and differences of power, prestige, resources in social groups, deprived groups struggle against the system and they become terrorists. Lack of democratic system also leads terrorist activities like political terrorism [18]. The most common cause amongst all was poverty and economic exploitation of people. A society with poverty, hunger, low rate of literacy had more chances to rapidly flourish terrorist activities [10].

Our reactions are more likely to be aggressive in situations where experience has taught us that aggression pays. Children whose aggression successfully intimidates other children may become more aggressive. Animals that have successfully fought to get food or mates become increasingly ferocious [8]. Different cultures model, reinforce, and evoke different tendencies toward violence. For example, crime rates are higher and average happiness is lower in countries marked by a great disparity between rich and poor [8]. Like all behavior, aggression arises from the interaction of persons and situations [9].

Once aggressive behavior patterns are established, it is difficult to change easily. To foster a kinder, gentler world we had best model and reward sensitivity and cooperation from an early age, perhaps by training parents to discipline without modeling violence. Modeling violence screaming and hitting is precisely what exasperated parents often do. Parents of delinquent youngsters typically discipline with beatings, thus modeling aggression as a method of dealing with problems [8]. They also frequently cave into reward their children's tears and temper tantrums. Observing Models of Aggression Parents are hardly the only aggression models. Therefore, most terrorists may acquire aggressive behaviors early in their life as a result of violent parental role models.

Observing TV violence tends to intensify people's cruelty and lead individuals to respond aggressively when provoked. Social psychologists attribute the media's influence partly to the social scripts (mental tapes for how to act, provided by the culture) they portray. When we find ourselves in new situations, uncertain how to act, we rely on social scripts. After so many action films, youngsters may acquire a script that gets played when they face real-life conflicts. Challenged may "act like a man” by intimidating or eliminating the threat. Likewise, after viewing the multiple sexual innuendoes and acts found in most prime-time TV hours often involving impulsive or short-term relationships youths may acquire sexual scripts they later enact in real-life relationships [18]. Music lyrics also write social scripts. In one set of experiments, German university men who listened to womanhating song lyrics administered the hottest Chile sauce to a woman and recalled more negative feelings and beliefs about women. Man-hating song lyrics had a similar effect on the aggressive behavior of women listeners [19]. Therefore, terrorists' aggressive behavior may be triggered by different environmental factors in general.

From the above discussions, every human behavior (normal or abnormal) is the result of environmental factors. Therefore, I can conclude that environmental factors play a great role for every individual's personality and behavior; especially aggression. The genetic factors may play only moderating roles. From the above discussions, everybody can feel him/herself as a member of every human race in the world. That is because; there is little biological difference with in the human gene. I strongly oppose the concept of discriminating people based on their religion, name, language, political ideology, ethnicity, etc. For instance:

- If I were an Arabic citizen, I would most probably the follower of Islamic religion.

- If I were an Iraq citizen, my name would most probably Mohammed or Mubarak.

- If I were UK citizen, I would an English language speaker.

- If I were an American citizen, I would the supporter of either the Democrat or Republican Party.

- If I were Russian citizen, I would from Caucasian, Chuvashs, Ukrainian, or Kazakhs, etc. ethnic group.

However, I am an Ethiopian as a result, my religion, name, citizenship, language and ethnicity is different from the above mentioned variables. Therefore, where is the true origin of human difference? 
People seek whatever pleasant experience in their life journey. People do not want to see any suffer for themselves, close relatives and their citizens in general. No one could happy by the death of his/her close relatives, by the oppression of his/her citizens, by the pain of his/her mother, by the illness of one's children, etc. unless that individual is in the state of abnormal mind. However, it is common to observe individuals who feel happy by the blood and death of others, feel comfort by the pain of others, get satisfaction through beheading the neck of others and enjoying by the tear of mothers lost their sons/daughters in this modern world. Sometimes, I tried to correlate just modernity and inhumanity goes to the positive direction of the normal distribution cure. This is to mean that, as someone becomes more civilized, he/she losses his/her sense of humanity and being kind for others. Why people act a devil action even it is difficult to talk about their action over others? Why some people get satisfaction observing the blood of the innocents?

In my belief, everybody who is in the state of normal mind needs something pleasant thing from somebody else. Therefore, in symmetrical reaction that individual should feel the interest of others just like as he/she seeks pleasant experience from others. The humanistic psychologists commonly used the word "empathy". It is to mean that everybody should put him/herself in the others' shoes in order to understand their feelings and emotions more. However, why do people commit brutal action upon others but they do not like to experience that action upon themselves?

1) People need to see their mothers feel happy but, they enjoy by the tears of other's mother.

Why?

2) People need to have long ages, peace, love and harmony in their life time but, they made to miscarriage or aborting other's life earlier.

Why?

3) People need to live with their wives, children, mothers and fathers but, they strive to separate others from their close relatives.

Why?

4) People need to contribute memorable deeds to their country but, they kill others who can contribute memorable tasks for their country.

Why?

5) People need to avoid stress and to have peace in their life but, they create chaos, confusion and tension on other's life.

Why?

6) People need to live in a city with full of infrastructure but, they damage infrastructures of others' city.

Why?

7) People need to take a rest after completing their daily tasks but, they make to awake others from their good sleep.

Why?

8) People need to gain reward and appreciation to their achievements but, they fail to pay the salary of workers in their company.

Why?

9) People need to build a bridge to pass through but, they block others not to transfer destroying the bridge. Why?

10) People need to have anti-virus software for their computers but, they develop virus software that can attack computers.

Why?

11) People need to escape from anything that can produce pain but, they inflict pain on others.

Why?

12) People need help from others at the time of difficulty but, they block the way that others can get a support from somebody else.

Why?

Therefore, I am kindly request you to answer the "why" questions and if you have full justification to act a bad thing on others but you do not like that bad thing for yourself, you have to revise being a human. You missed some elements that make you to be a human. That is why I am suggesting you either to construct your personality again or to avoid yourself from this world. In my future research, I will come up with the satisfactory answers and explanations for the "why" questions listed above. 


\section{Conclusion}

Terrorism is a global threat. It does not favor language, color, religion, race, political ideology, etc. Therefore, everybody should fight against terrorism joining hands. Terrorists try to give a religious or political coverage for their devil actions. However, it is not the true reason for their action; instead they are striving to eliminate every human from the world attributing human made differences. That is because, there is no difference among the human gene, and differences are created by us. Generally, it is not a persuasive reason to kill people attributing religious, political, racial and other differences.

\section{Recommendations}

- People should not strive to abolish their own gene from the world.

- There is no true or little biological difference among people; therefore, people should not create turmoil attributing difference. Every human difference is developed as a result of the social environment or there is no true human difference.

- People should create harmony, peace, love, care for and stability avoiding any human made differences.

- Terrorism is a movement to abolish human gene from the earth; as a result everybody should defend his/her own gene from the attack of terrorism joining hands.

- Everybody should feel sense of belongingness and concern for every attack that commit by terrorist groups upon the human race in general.

\section{References}

[1] Muhammad, S. and Muhammad, R. (2012) Perceptions towards Terrorist Activities in Pakistan: A Case Study of Maddrassa Background Students. World Applied Sciences Journal, 19, 1284-1288.

[2] Altheide, D.L. (2004) Consuming Terrorism. Symbolic Interaction, 27, 289-308. http://dx.doi.org/10.1525/si.2004.27.3.289

[3] Charlotte, F. (2005) Young People’s Perception of Being Safe Globally \& Locally. Social Indicators Research, 80, 3149.

[4] Sullivan, M.P. (2005) Cuba and the State Sponsors of Terrorism List. (Order Code RL32251). Congressional Research Service: The Library of Congress. http://www.fas.org/sgp/crs/terror/RL32251.pdf

[5] Shughart, W. (2006) An Analytical History of Terrorism, 1945-2000. Public Choice, 128, 7-39. http://dx.doi.org/10.1007/s11127-006-9043-y

[6] Blanchard, C.M. (2008) Islamic Religious Schools, Madrasas: Background. (Order Code RS21654). Congressional Research Service: The Library of Congress. http://fpc.state.gov/documents/organization/61473.pdf

[7] Gupta, R. (2004) Terrorism Communalism and Other Challenges to Indian Security. Kalpaz Publication, Delhi.

[8] David, G. (2010) Psychology. Worth Publisher, United States of America.

[9] Kalat, J.W. (2008) Introduction to Psychology. North Carolina State University, United States of America.

[10] Dijksterhuis, A. and Bargh, J. (2001) The Perception-Behavior Expressway: Automatic Effects of Social Perception on Social Behavior. Advances in Experimental Social Psychology, 33, 1-40. http://dx.doi.org/10.1016/S0065-2601(01)80003-4

[11] Haueisen, J. and Knosche, T. (2001) Involuntary Motor Activity in Pianists Evoked by Music Perception. Journal of Cognitive Neuroscience, 13, 786-792. http://dx.doi.org/10.1162/08989290152541449

[12] Bertenthal, B., Longo, M. and Kosobud, A. (2006) Imitative Response Tendencies Following Observation of Intransitive Actions. Journal of Experimental Psychology: Human Perception and Performance, 32, 210-225. http://dx.doi.org/10.1037/0096-1523.32.2.210

[13] Fogassi, L., Ferrari, P.F., Gesierich, B., Rozzi, S., Chersi, F. and Rizzolatti, G. (2005) Parietal Lobe: From Action Understanding to Intention Understanding. Science, 308, 662-667. http://dx.doi.org/10.1126/science.1106138

[14] Wicker, B., Keysers, C., Plailly, J., Royet, J.-P., Gallese, V. and Rizzolatti, G. (2003) Both of Us Disgusted in My Insula: The Common Neural Basis of Seeing and Feeling Disgust. Neuron, 40, 655-664. http://dx.doi.org/10.1016/S0896-6273(03)00679-2

[15] McDermott, T. (2005) Perfect Soldiers: The 9/11 Hijackers: Who They Were, Why They Did It. HarperCollins, New York.

[16] Asfa, R. and Ahmed, M. (2012) Impact of Terrorism on Global Security: A Pakistani Perspective. Berkeley Journal of 
Social Sciences, 2, 1-9.

[17] Krueger, A. (2007) What Makes a Terrorist? The American. www.american.com

[18] Kunkel, D., Cope-Farrar, K., Biely, E., Farinola, W.J.M. and Donnerstein, E. (2001) Sex on TV (2): A Biennial Report to the Kaiser Family Foundation. Kaiser Family Foundation, Menlo Park.

[19] Fischer, P. and Greitemeyer, T. (2006) Music and Aggression: The Impact of Sexual-Aggressive Song Lyrics on Aggression-Related Thoughts, Emotions, and Behavior toward the Same and the Opposite Sex. Personality and Social Psychology Bulletin, 32, 1165-1176. http://dx.doi.org/10.1177/0146167206288670 